\title{
Egészségügyi mobilapplikációkra történő használati szándék mérése UTAUT-modellben - tanulmány egy online felmérés eredményei alapján
}

Mindennapjaink szerves részét képezi az információgyüjtés, -menedzselés és -felhasználás, melyekben - a digitális kultúra az életvitelünk felgyorsítására és az azonnaliságra vonatkozó jellegzetességei miatt - kiemelt hangsúlyt kapnak a mobileszközök és az azokon futó applikációk. Ezek között egy markáns trend az egészséggel kapcsolatos alkalmazások köre, melyek a tudatos életmód terjedésével, illetve a tömegsport népszerüségének növekedésével számos területen segíthetik a felhasználókat. A szerzők elsődleges célkitűzése volt, hogy a fiatal felnőttek körében megvizsgálják, milyen tényezők hatnak leginkább egy egészségügyi mobilapplikáció használati szándékára. Ennek megfelelően egy módosított UTAUT-modellel és a hozzá tartozó kérdőív segítségével mérték fel a kitöltők attitűdjét. A tanulmányból kiderül, hogy a leginkább befolyásoló tényező az egyén motivációja és az egyénre ható szociális ráhatás. A szerzők ezenfelül vizsgálták az egyes egészségügyi mobilapplikációk típusait, használatuk gyakoriságát, és az egyes típusok leggyakoribb feladásának okait. A tanulmány útmutatást adhat a 18 és 35 év közötti korosztály számára történő jövőbeli fejlesztéseknek, mivel a mobilapplikációk piacán ez a korcsoport az, amely a legtöbb applikációt használja. A munka emellett az egészségtudatosság egy szélesebb körű alkalmazására is rámutat. A szerzők továbbá lehetőségként vázolják fel, milyen módszerekkel érdemes attraktívabbá tenni az alkalmazásokat.

Kulcsszavak: PLS, UTAUT, egészségügyi mobilapplikációk, mHealth

\section{Köszönetnyilvánítás}

A publikáció elkészítését az EFOP-3.6.1-16-2016-00022 számú projekt támogatta. A projekt az Európai Unió támogatásával, az Európai Szociális Alap társfinanszírozásával valósult meg.

\section{Szerzői információ}

Kovács Tamás, Debreceni Egyetem, Ihrig Károly Gazdálkodás és Szervezéstudományok Doktori Iskola

Várallyai László, Debreceni Egyetem, Gazdaságtudományi Kar, Informatikai és Logisztikai Intézet

Így hivatkozzon erre a cikkre:

Kovács Tamás, Várallyai László. „Egészségügyi mobilapplikációkra történő használati szándék mérése UTAUT-modellben ”. Információs Társadalom XXI, 1. szám (2021): 166 -187. = https://dx.doi.org/10.22503/inftars.XXI.2021.1.7

A folyóiratban közölt müvek

a Creative Commons Nevezd meg! - Ne add el! - Így add tovább! 4.0 Nemzetközi Licenc feltételeinek megfelelően használhatók. 


\section{Mobile health applications intention to use from perspectives of UTAUT - results from an online survey}

Collecting information, data management and utilization an integral part of our daily lives, due to the characteristics of digital culture and accelerating lifestyle the mobile devices and their applications are given emphasized role. Among these, one of the most important tendencies is pronounced of health-related applications via the spread of a healthy lifestyle and opportunities for mass sports popularity could help the users. The primary goal of the authors was to examine what factors influence young people's intentions to use a health mobile application. Accordingly, a modified UTAUT model and the related questionnaire survey were used to assess the attitudes of the respondents. The study highlights to the most influential factors are the individual's motivation and social influence. In addition, the authors examined the types of mobile health applications, their frequency of use, and the most common reasons for abandoning usage. The manuscript points to a broader application of health awareness. Based on the results, the authors outline how the developers could make their applications more attractive.

Keywords: PLS, UTAUT, applications in healthcare, mHealth

\section{Acknowledgments}

The publication supported by EFOP-3.6.1-16-2016-00022 project. The project is supported by the European Union and co-financed by the European Social Fund. 


\section{Bevezetés}

\section{Problémafelvetés}

Manapság a felgyorsult életvitelünk, a mozgáshiány, valamint több, egészségre káros tényező befolyásolja mindennapjainkat, mint a dohányzás, a túlzott alkoholfogyasztás, a túl zsíros és füszeres ételek fogyasztása vagy éppen a streszsz. Számos kutatás bizonyította már (World Health Organization 2013; OECD Health statistic 2017; Erdei és mtsai. 2017), hogy hazánk az Európai Unióban élen jár az elhízottak számát tekintve, mindemellett aggasztó, hogy a gyermekkori elhízás is növekvő tendenciát mutat (Kovács 2018). Az egészséggazdaság részeként e problémákra igyekeznek megoldást vagy épp segítséget nyújtani a különböző szoftverfejlesztő cégek, akik applikációikkal képesek segíteni a felhasználóikat. A mobiltechnológiák alkalmazása az egészségügyben nem újkeletü, már az mHealth keretein belül is megjelent mint egészségügyi adatokat gyűjtő és egyes terápiát támogató eszközrendszer. A kétezres évek közepétől, az okostelefonok elterjedésével ez még személyre szabottabbá és egyszerűbbé vált. Az információs társadalmunk részeként fokozott digitalizációnak és nagy mennyiségű adatnak, információnak vagyunk kitéve. Az okostelefonokat és más okoseszközöket szinte minden generáció használja, melynek egyik oka, hogy azok egyre olcsóbbá és könnyebben elérhetővé váltak. 2018-ban a Hootsuite (Hootsuite és Social 2018) jelentése szerint a magyar felnőtt lakosság 96 százalékának van valamilyen mobiltelefonja, amelyből legalább 65 százalék már valamilyen okostelefont használ (Nemzeti Média- és Hírközlési Hatóság 2018).

\section{Az egészséggazdaság fogalmi keretei}

A kutatás pontos lehatárolása érdekében érdemes megvizsgálni az egyes fogalmakat. A kezdetekben Telemedicina vagy teleHealth néven vált ismertté az a rendszer, amely valamilyen telekommunikációs eszközzel támogatta a hagyományos egészségügyet, például telefonhívással vagy SMS-küldéssel segítették a pácienst. Az internet megjelenését követően újabb fogalom jelent meg az egészségügyi szektorban eHealth néven. A kétezres évek elején a hangsúly az IKT-eszközökkel támogatott adatgyüjtésekre és a viselhető eszközök lehetőségeire koncentrálódott. Ezt követően, az okostelefonok robbanásszerű elterjedésének hatására, támogató jelleggel a különböző mobileszközök is bekerültek az egészségügybe (Kő és Szabó 2015). Ezt számos gyártó felismerte, így egyre többen fejlesztettek egészségügyi mobilapplikációkat a páciensek és az orvosok számára. A tanulmány részleteiben az egészségügy és egészséggazdaság e területével foglalkozik. Megvizsgálja van-e használati hajlandóság a fiatalok körében egészségügyi mobilapplikációkra, illetve milyen tényezők befolyásolják a használatot. Tény, hogy a nyugati országokban már bevett 
szokásnak számít az egészségügyben a telefonos alkalmazások használata, világszinten az Egyesült Államok ebben messze az élen jár. Egy ezt vizsgáló tanulmány az amerikai orvosok szemszögéből közelítette meg a kérdést, melyben arra az eredményre jutottak, hogy a kutatásban részt vettek 42\%-a írna fel terápiás jelleggel mobilapplikációkat, míg 37\%-uk még csak nem is ismeri a piacon lévő megoldásokat (Boudreaux és mtsai. 2014). Több kutatás is rámutat arra, hogy az mHealth keretein belül működtetett orvos-páciens tanácsadó és támogató mobilalkalmazásokat magas elégedettség kiséri (Lee és mtsai. 2018; Han és Lee 2018).

Egészséggazdaság keretein belül beszélnünk kell az egészségfogyasztásról és annak megoszlásáról. A szakirodalomban és a gyakorlatban egyaránt két megközelítéssel találkozhatunk. Az első középpontjában az egészségmegtartó magatartás, illetve az ehhez kapcsolódó fogyasztás, például gyógyhatású termékek, egészségfejlesztéssel kapcsolatos tevékenységek és termékek, valamint a gyógyszerek, valamint az egészséges életmóddal kapcsolatos szolgáltatások, végül pedig az egészséges étkezés állnak. A második megközelítés a betegség melletti egészséggondozás, valamint a rekreáció különböző formáira terjed ki. Az egészséggazdaság elég szerteágazó mivoltát mi sem bizonyítja jobban, mint egy 2012-es TÁRKI-kutatás (Szivós és Tóth 2013), ahol a célcsoportot (fiatal felnőttek) arról kérdezték, milyen szavakkal azonosítják az egészséget, mit értenek ez alatt a fogalom alatt. A legtöbben a betegségek nélküli állapotra asszociáltak, majd a család egészségére, többen pedig a testi-lelki egészséget jelöltek meg a válaszukban. E fogalmakat alapul véve, az egészségügyi applikációk alatt az egészségmegtartó és egészséggondozó és rekreációs applikációkat értjük. Az alkalmazások fejlesztési irányából megközelítve beszélhetünk a szakembereknek, orvosoknak fejlesztett, úgynevezett támogató applikációkról (például Isabel $^{1}$ ), melyek a tünetek, hatóanyagok egyidejü alkalmazásának lehetőségében segítenek. A másik oldalról pedig a páciensek vagy végfelhasználók számára készített alkalmazásokról, melynek döntő többsége támogató jellegű. Csoportosító tényezőként több lehetőséget alkalmazhatunk. Az egyik ilyen az árazás, melyben megjelenik az ingyenes, az egy összegben kifizetendő és a periodikus fizetés (havidíjas, éves stb.) A másik - melyről a tanulmányban is szó esik - az alkalmazások hasznosításának módja, tehát hogy a felhasználó milyen céllal használja az adott appot. Ez utóbbiak a különböző diétákra vagy kalóriaszámlálókra specializálódott vagy az egészségi állapot monitorozására (vérnyomás, koleszterin, vércukorszint, BMI, testsúly, alvás) használt applikációk, a teljesítménymonitorozás (futás, biciklizés stb.), az aktív wellness és a hozzá kapcsolódó alkalmazások, a lépésszámlálók és aktivitásmérők, illetve a komplex egészségügyi alkalmazások, melyekben több, az előzőekben felsorolt funkció van ötvözve. Ezen alkalmazások több ezrével vannak jelen a különböző platformok áruházaiban, melyek közül számos ingyenes megoldás is elérhető. 2017-

${ }^{1}$ https://www.isabelhealthcare.com/ 
ben az okostelefonnal rendelkezők közül minden második felhasználó telepített valamilyen egészségügyi alkalmazást (Lupton 2014; Boudreaux és mtsai. 2014).

Mivel a kutatás elsősorban a mobiltelefonos, azon belül is az okostelefonos applikációkra terjed ki részleteiben, így fontos megvizsgálni a hazai használat módját. A cég kutatásából kiderült, hogy életünk során milyen tevékenységekre használjuk. Fontos kiemelni, hogy az okostelefonok rendszeralkalmazásait és beépített funkcióit prezentálja a következő ábra (1. ábra).

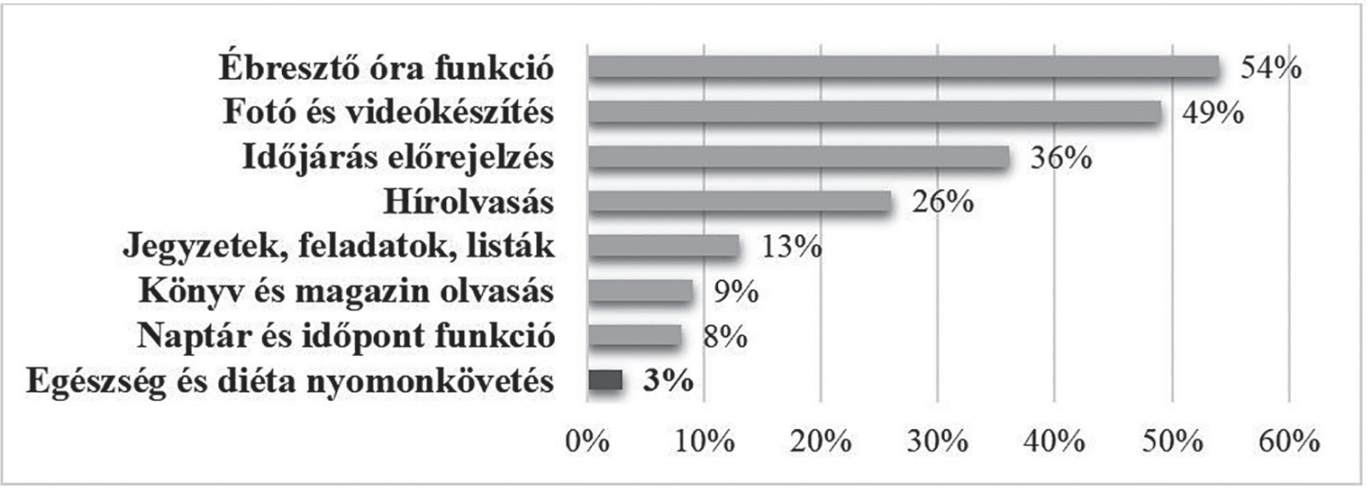

1. ábra: Okostelefon használat életvitelünk során (Forrás: Hootsuite 2018 alapján)

Látható, hogy legtöbben ébresztőóraként használják telefonjukat, valamint a válaszadók közel fele fotó és videokészítésre is okostelefonjuk után nyúl. Ezenfelül a különböző listák, napi teendők jegyzetelése, hírolvasásra, időjárás-előrejelzésre, sőt a válaszadók 3\%-a már az egészségükkel kapcsolatos tevékenységre, például diétájukhoz, valamint kalóriaszámításhoz is használják. Emellett fontos, hogy az okostelefonos applikációval töltött megnövekedett idő a fiatalok körében jellemző (Kang, Mee, és Johnson 2015), ahol a letöltött alkalmazások száma átlagosan 28, míg a 18-35 éves korosztály több applikációt használ és kevesebb ideig (Nielsen 2014).

Az egészségügyi mobilapplikációk klasszifikációja a korábbi években számos kutatás alapját képezte hazai és nemzetközi szinten (Höhn és mtsai. 2016; Nwe és mtsai. 2020). Soós és Törőcsik többek között megkülönböztet kardiovaszkuláris és a hozzájuk kötődő kockázatmérő alkalmazásokat, szakértői támogató jellegüeket, kiegészítő eszközök alkalmazásait, tracking típusú, azaz nyomonkövetést elősegítő alkalmazásokat, mentális betegségek támogató alkalmazásait, valamint külön számba veszi a veszélyhelyzeti, azon belül is az orvosi menedzsment alkalmazásokat, betegségek terjedésének monitorozását, valamint a háttérmunkát támogató adminisztratív alkalmazásokat (Soós és Törőcsik, 2015). Az alkalmazások sokszínűsége mellett kutatásuk rámutat, hogy a felhasználok számára a hitelesség és az elérhetőség a legfontosabb ezen a piacon. Seabrook és munkatársai azt vizsgálták, milyen célcsoportnak milyen típusú alkalmazásokat fejlesztenek az egészségügyben. Eredményeik alátámasztják, hogy a legtöbb fejlesztés nyilvános, tehát minden felhasználó használhatja őket, de emellett léteznek kifejezetten a klinikai dolgozók és a páciensek számára, 
illetve az orvosok, a medikushallgatók, az ápolók és végül az egyéb kategóriába sorolt applikációk. Típuukat tekintve a legtöbb alkalmazás referencia és tudástár, az oktató és támogató, a nyomonkövetést szolgáló, a monitoring, azaz a folyamatos ellenőrzést lehetővé tevő alkalmazás, de emellett megjelennek a kalkulátorok, a diagnózishoz kapcsolódóak, az emlékeztetők, az alternatív medicina témakörét érintő, valamint a diéta és a motivációt elősegítő alkalmazások is (Seabrook és mtsai. 2014). Yasini és munkatársai a 567 legtöbbet letöltött egészségügyi applikációt összesen 31 altípusba sorolta, amelyek eredményei közel azonosak voltak az előző kutatások eredményeivel. Ezzel szemben Greve és munkatársai összesen 5 különböző altípust említenek munkájukban, melyek a tudás transzfer, az egészségügyi menedzsment, az egészségügyi szervezetek (időpontfoglalás lebonyolítása) applikációi, az adatok monitorozására használt, valamint terápiás jellegű alkalmazások voltak (Greve és mtsai. 2020). A hazai applikációk hajlandóságára történő kutatást nem találtak a szerzők.

A hazai sportolási szokások tekintetében elmondhatjuk, hogy az unióban megkérdezettek 46\%-a soha nem sportol, míg Magyarországon ez az arány 56\% az Európai Bizottság 2017 decemberi felmérése alapján. Ez a korábbi 2013-as felmérés eredményeihez képest közel 9\%-os romlást jelent hazai szinten (Europian Comission, 2018). A legtöbb testmozgást azok végzik, akik keveset tudnak mozogni a munkájuk során. A szellemi tevékenységet dolgozók 58\%-a heti rendszerességgel végez rekreációs sportolási tevékenységet, akik közül minden második legalább négy órát edz alkalmanként. A nem dolgozók közül a tanulók a legaktívabbak, és az is megállapítható, hogy az egyre idősebb korcsoportok sportolási szokásai egyre alacsonyabb értékeket mutatnak (KSH, 2019). Ezzel egyidejűleg a technológia egyes tömegsportokban és sportágakban egyre többször megjelent monitorozás és teljesítményoptimalizálás céljából, teret adva a különböző eszközök és applikációk könnyebb elterjedésére (Amaro és Patrao, 2016; Aroganam és mtsai. 2019). Azonban azt sem felejthetjük el, hogy a jelenlegi pandémia okozta helyzetre való tekintettel a sportolási lehetőségeink beszűkültek, edzésformáink megváltoztak, és az egyes applikációk lehetőségei felértékelődtek.

\section{UTAUT-modell kialakulása és használata}

A technológiai fejlődés növekedésével egyre fontosabbá válik, hogy milyen tényezők befolyásolják a társadalmat azok elfogadását illetően. Az egyes innovációk fogyasztói elfogadására számos elméleti modellt alkottak meg, melyekkel tesztelni tudják afejlesztések előnyeit és hátrányait. Az első ilyen a Technológia Elfogadás Modell, röviden csak TAM, Davis nevéhez kötődik (Davis 1989), amelyben az elfogadás hátterében álló faktorokat igyekezett vizsgálni, a személyi számítógépek és rendszerek munkahelyen történő alkalmazására. Ezt a modellt Davis, majd később kollégái más változókkal bővítették, ahol már a külső tényezőket is igyekeztek figyelembe venni, például a tapasztalatot vagy 
az önkéntességet, így a modell két másik variánsa is bekerült az empirikus modellek közé TAM2- (Venkatesh és Davis 2000) és TAM3-modell (Venkatesh és Bala 2008) néven. Ezzel párhuzamosan Venkatesh és kollégái nyolc modellt egyesítve elkészítették a Technológiaelfogadás és -használat egységesített elméletét, azaz a UTAUT-modellt (Venkatesh és mtsai. 2003), beleépítve a Rogers-féle diffúziós elméletet, a motivációs modellt, a technológia elfogadás modelljét, a logikus cselekvések elméletét, a társadalmi kognitív elméletet, a tervezett viselkedés elméletét, a TPB-modellt, valamint a személyi számítógép használatának modelljét.

A UTAUT négy változóval közvetlenül méri az adott technológia használati szándékát, továbbá közvetve a tényleges használatot. E változók a várható teljesítmény, a várható erőfeszítés, a társadalmi hatás, valamint az elősegítő feltételek. Emellett négy moderáló változó is bekerült a modellbe: nem, kor, tapasztalat és önkéntesség. A modell értelmezéséhez fontos átlátni, hogy az egyes változók és a hozzájuk tartozó kérdések mit mérnek pontosan. A várható teljesítmény (PE) azt méri, hogy az adott technológia mennyire segíti az adott munkában vagy cselekvésben a használóját. A várható erőfeszítés (EE) azt, hogy a felhasználó mekkora erőfeszítésnek ítéli meg az adott technológia használatát. A társadalmi hatás (SI) azt fejezi ki, hogy a technológia használója mennyire érzi fontosnak, mit gondolnak róla a számára fontos emberek. Az elősegítő feltételek (FC) változó pedig rámutat az adott technológia használatához szükséges tudás, készség létére, amely könnyíti az adott technológia használatát. A UTAUT-modellt 2012-ben átdolgozva Venkatesh és kollégái kiterjesztették UTAUT2 néven (Venkatesh, Thong, és Xu 2012), hogy a modell ne csak vállalati körülmények között legyen képes technológiaelfogadást mérni, így napjainkra számos módosított modell jelent meg ezen modellek változóinak variálásával. A következő táblázat prezentálja a különböző technológiaelfogadás-modellek használatát hasonló kutatások során (1. táblázat).

\begin{tabular}{|l|c|l|}
\hline \multicolumn{1}{|c|}{ Terület } & Modell & \multicolumn{1}{|c|}{ Referencia } \\
\hline $\begin{array}{l}\text { elektronikus orvosi nyilvántartó } \\
\text { rendszer }\end{array}$ & UTAUT & (Wills 2008; Alsyouf és Ishak 2018) \\
\hline $\begin{array}{l}\text { képalkotó diagnosztikai újdonság } \\
\text { elfogadása radiológus szakorvosok } \\
\text { körében }\end{array}$ & UTAUT & (Duyck és mtsai. 2008) \\
\hline mobil egészségügyi szolgáltatás & TAM & (Hung és Jen 2012) \\
\hline $\begin{array}{l}\text { orvosképzésben történő } \\
\text { mobilapplikációk használata }\end{array}$ & TAM & (Briz-Ponce és García-Peñalvo 2015) \\
\hline mobil egészségügyi alkalmazások & $\begin{array}{c}\text { TAM, } \\
\text { UTAUT }\end{array}$ & $\begin{array}{l}\text { (Mohamed és mtsai. 2011; } \\
\text { Ndayizigamiye és Maharaj 2016) }\end{array}$ \\
\hline
\end{tabular}

1. táblázat: Példák hasonló területen alkalmazott technológia elfogadás modellek (saját szerkesztés, 2020) 
A szakirodalomra alapozva végül a UTAUT-modell került kiválasztásra, illetve annak egy változóval való bővítése. Ezt Keszei és Zsukk munkássága támasztotta alá leginkább, ahol bemutatásra került a technológiai innovációs modellek jelentős része, előnyeikkel és hátrányaikkal (Keszei és Zsukk 2017).

\section{Primer kutatás}

A kutatás primer adatgyüjtése kérdőíves megkérdezéssel lett elvégezve, míg kiegészítésként szekunder adatok, nemzetközi és hazai adatbázisok lettek felhasználva. A kutatás a strukturált szakirodalmi gyüjtéssel, feldolgozásával, majd szintetizálásával kezdődött, amelyhez a felhasznált adatbázisok és repozitóriumok köre: a PubMed, a DEA, a ScienceDirect, a GoogleScholar és a ResearchGate voltak. A szekunder adatforrások hazai és nemzetközi viszonylatban az OECD, KSH és a WHO volt, valamint a témához illeszkedő releváns kutatások eredményei.

A kérdőív célcsoportja elsődlegesen a hazai fiatal felnőtt lakosság (18-35 éves), azon belül pedig a Debrecenben és a szűk, 20 km-es vonzáskörzetében élők voltak. A kérdőív kitöltése teljesen anonim módon, a részvétel pedig önkéntesen zajlott. A kérdések köre az általános adatokon túl kitér az egészség témakörében használt alkalmazásokra, azok fejlesztési lehetőségeire, használatukra és a leggyakoribb feladások okaira egyaránt. A primer kutatás CAWI (Computer Assisted Web Interviewing), online lekérdezési módszerrel lett elvégezve. A mintavétel hólabda módszerrel történt, közösségimédia-felületen (Facebook-csoportok) megosztva, amelyet 14 napig érhettek el. Így 151-es elemszámot sikerült elérni, amely a célcsoport korosztályát 94,1\%-ban fedi le.

Mivel a kutatás elsősorban a különböző egészségügyi applikációk használati hajlandóságát méri, így a UTAUT-modell (technológia elfogadásának és használatának egyesített elmélete) adaptálása jelenik meg a kutatási koncepció alapjának. A modell változói 1-től 5-ig tartó Likert-skálán lettek mérve, ahol az 1-es a „teljesen nem értek egyet” míg az 5-ös a „teljesen egyetért”-et jelentette. A kérdőívben deklarálásra került, hogy a szerzők mit is értenek az egészségügyi mobilapplikációk alatt. Megfogalmazásunk szerint az egészségügyi alkalmazások, beleértve az egészségmegőrző (fitnesz-, wellness-applikációkat), valamint a betegség kezelésére és monitorozására használt alkalmazásokat egyaránt. A kutatás nem törekszik a reprezentativitásra a szük célcsoport lehatárolása miatt. A statisztikai elemzést az SPSS 22.0 szoftverrel, míg az útelemzés SmartPLS programmal készült. Kiegészítésként az ábrák elkészítéséhez és egyes számítások elvégzéséhez a Microsoft Office Excel 2016 program lett használva.

\section{Vizsgálati módszer: Strukturális Egyenletek Modellje (SEM)}

A látens változókkal való modellezés számos területen megjelent már korábbi tanulmányok során, ahol az egyik leggyakrabban alkalmazott módszer a 
strukturális egyenletek modellje (Structural Equation Modeling), azaz a SEM volt. A SEM két legközkedveltebb technikája a CB-SEM, másnéven a kovarianciaalapú megközelítés, valamint a PLS-SEM, ami egy varianciaalapú módszer. A PLS-SEM-et szokták PLS-regressziónak vagy útelemzésnek is nevezni. A két módszer lényege, hogy a látens változókat, melyeket közvetve nem tudunk mérni, kizárólag manifeszt változók segítségével vizsgáljuk (Kazár 2014).

Előnye, hogy regresszió- és szimultán faktoranalízist is elvégezhetünk vele, amellyel létrehozhatunk látens változókat, valamint megvizsgálhatjuk a közöttük fennálló kapcsolatokat is (Sajtos és Fache 2005). A SEM két egységből, egy belső mérési modellből és egy külső mérési modellből áll. A belső modell nyilai, az „utak” a strukturális modellt adja, ahol a faktorok közötti kapcsolatokat mérjük, míg a külső modell esetén a látens változók közötti összefüggéseket regressziós egyenletekkel vizsgáljuk.

Fontos, hogy a modellben a látens változók közötti utaknak csak egy iránya lehet. A látens változókat exogén, míg a függő változókat endogén változónak tekintjük. A látens és indikátor változók közötti kapcsolatok iránya alapján megkülönböztethetünk reflektív és formatív mérési modellt. Ezek ok-okozati kapcsolatokat jelentenek a modellben. A modellalkotás során mind a kettőt szabadon használhatjuk (PLS-SEM), azonban Hair és kollégái a multikollinearitás problémájára hívják fel a figyelmet (J. F. Hair, Ringle, és Sarstedt 2011). A PLS-útelemzés nagy előnye a kovarianciaelemzéshez (CB) képest, hogy viszonylag kis elemszámmal is elvégezhetők a vizsgálatok, továbbá nem előfeltétele a normális eloszlás. Hátránya, hogy egyértelmű illeszkedési mutatóval nem írható le a modellünk, míg a CB esetében számos mutató szolgál az illeszkedés pontos meghatározására. További hátránya, hogy közvetlenül nem tesztelhetjük az útegyütthatókat a normális eloszlás hiánya miatt, azonban a bootstrapping regressziós együttható tesztjével ez a hátrány feloldható. E számítások elvégzésére számos program nyújt segítséget számunkra, mint például a LVPLS, PLS-Graph, valamint a szerzők által használt SmartPLS (Henseler, Ringle, és Sinkovics 2009).

\section{Kutatási modell felépítése}

Mivel a kutatás nem vállalati körülményeket vizsgál, hanem átlagos egészségügyi mobilapplikáció-használati hajlandóságot, így az eredeti UTAUT-modell módosításra került, ahol a szerzők elhagyták az egyes változókat, míg más helyen bővítettek (2. ábra), ahogy azt az irodalomban számos más szerző is tette korábban (1. táblázat). A UTAUT2-modellből bekerült a hedonista motiváció (HM) változó a belső mérési modellbe. Ennek az egyik legfőbb oka, hogy az egészségünkkel kapcsolatos applikációkat nagy valószínűséggel önszántunkból töltjük le és használjuk, így ennek a hatása akár szignifikánsan is kimutatható a modell elemzése során. Ezzel szemben azonban nem került be az ár-érték arány (PV), melynek oka, hogy a vizsgálat elsődlegesen ingyenes és platformfüggetlen alkalmazásokra terjedt ki. Továbbá a tényleges használatot 
nem vizsgáltuk, mivel a cél a használati szándékra történő technológia elfogadás mérése volt. A teljes modellből a moderáló változókat sem vizsgáltuk, melynek oka a szűk célcsoporti lehatárolás volt.

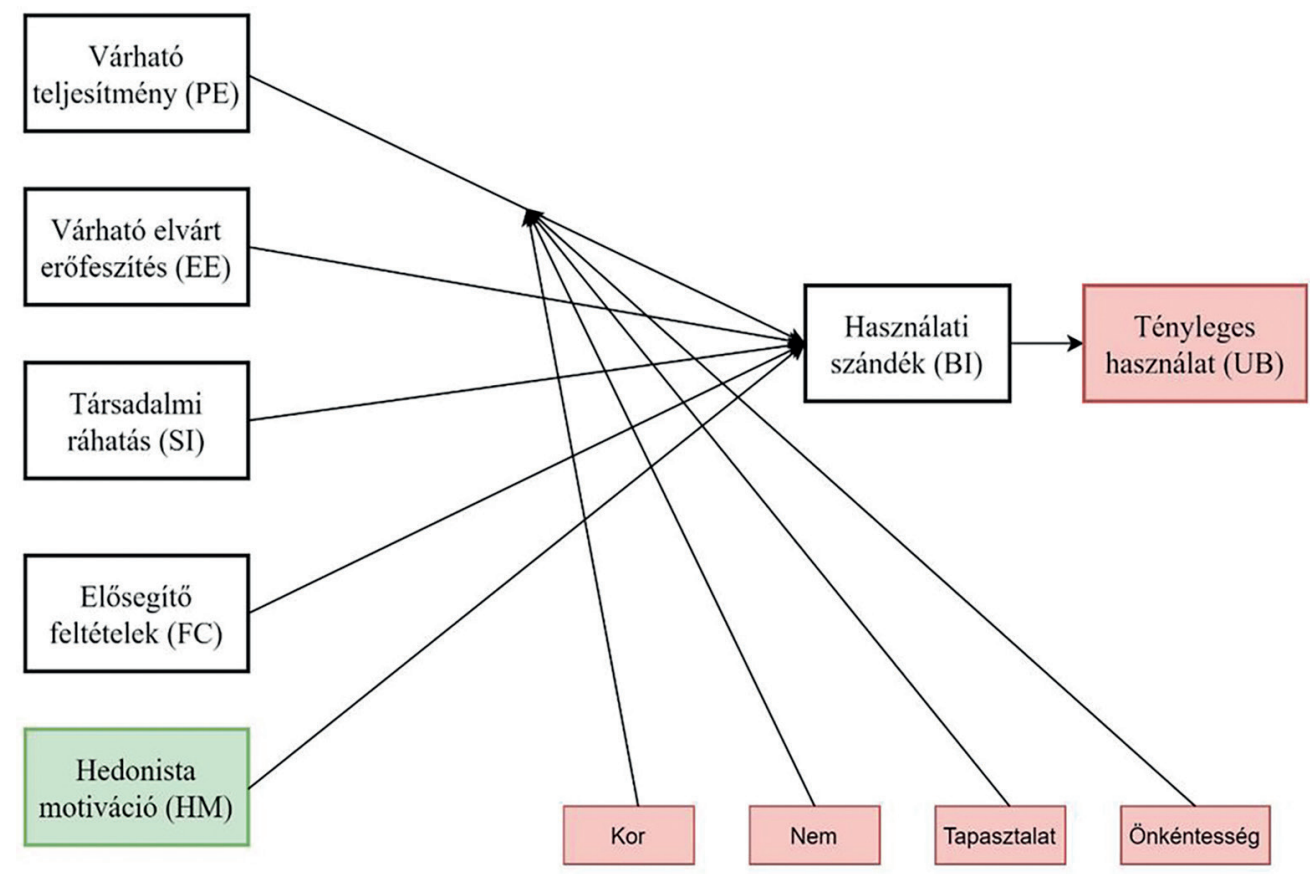

2. ábra: A módosított UTAUT modell felépítése (saját szerkesztés, 2020)

Látható, hogy a szerzők nem fogalmaztak meg hipotéziseket a tanulmányban, mivel az elemzés (PLS-SEM) exploratív, azaz feltáró jellegü, így csak az egyes változók közötti kapcsolatokat és azok erősségét próbáljuk szemléltetni egy módosított UTAUT-modell segítségével. Előzetes elvárásként a szerzők a motiváció előtérbe kerülését várták, ezért került ez külön változóként a modellbe.

\section{Kutatási modell konstruktorok bemutatása}

Használati szándék (BI)

Az egyes viselkedési formákat, mint egy új technológia iránti használati szándékot, több szerző a tevékenység végrehajtásaként, valamint egyfajta terveként definiálta (Davis és mtsai. 1992; Venkatesh és mtsai. 2003). Számos tanulmány rámutatott már, hogy pozitív kapcsolat van a használati szándék és a tényleges használat között (Ajzen és Fishbein 1980). Venkatesh és munkatársai a technológiaelfogadás meghatározójaként említi, mivel az eredeti modellben a négy független változó egyértelműen azonosítható és számos területen alkalmazhatónak nevezi (Venkatesh és mtsai. 2003). 
A várható teljesítmény alatt azt értjük, mikor a személy a technológia alkalmazásával elősegíti a tevékenysége során a teljesítményét. Ezt a modell extrinsic motivációjának is tekinthetjük, mivel a felhasználók egyfajta relatív előnyként tekintenek az új technológiára. A változó elméleti hátterében a hasznosság észlelése áll, amely a TAM-modellben is megjelenik (Shin 2009).

Szükséges várható erőfeszítés (EE)

A szükséges várható erőfeszítés a felhasználóktól elvárt invesztáció, amíg az adott technikát, technológiát megtanulja használni. Davis megállapítása szerint az emberek a könnyen használható és megtanulható alkalmazásokat, technikákat nagyobb valószínűséggel fogadják el, ez a használati szándékra és a tényleges használatra is pozitív hatással van (Davis 1989).

Szociális ráhatás (SI)

A szociális ráhatás vagy társadalmi ráhatás esetén a változó azt méri, mekkora jelentőséggel bír a megkérdezettek számára fontos személyek véleménye egy technológia használatát illetően. A változó a TAM2-modell szubjektív normák változójából származtatott Venkatesh munkája által (Venkatesh és mtsai. 2003). A változó a társadalmi státusz alapján méri a befolyásoltságot. Az alapelképzelés, hogy az egyén viselkedését befolyásolja, mások mit gondolnak a technológiához való hozzáállásáról. A használati szándék, tanulási motiváció és a társadalmi befolyásoltság dimenziójában Maldonado és munkatársai pozitív hatást állapítottak meg (Maldonado és mtsai. 2011).

Elősegítő feltételek (FC)

Az elősegítő feltételek változó segítségével azt mérhetjük, hogy a technológia elfogadásának alanya mennyire éli meg könnyítő feltételként, hogy az egység szervezeti és infrastrukturális háttérrel rendelkezik, ahol a technológia bevezetése történne. Jelen esetben a felhasználók technikai tudását és eszközellátottságát méri a változó. Chang egyik munkájában a földrajzi különbségeket is elemzi, miszerint az egyes területek szocializálódása miatt jelentős eltérések lehetnek a használati hajlandóság és a konstruktorok kapcsolatában (Chang 2012; Dajani 2016).

Hedonikus motiváció (HM)

A hedonikus motivációt a technológia használatából eredő élményként, szórakozásként határozhatjuk meg. A modellben az elfogadás terén az egyik leg- 
fontosabb szerepet tölti be, mivel a munka vagy tevékenység élvezeti értékét képes növelni (Van der Heijden 2004).

\section{Eredmények}

A kérdőív legfontosabb demográfiai jellemzőit a 2. táblázat taglalja részleteiben. A szűk célcsoporti szegmentálás miatt az eredmények nem tekinthetők reprezentatívnak. A vizsgálat elemszáma 151 fő volt, ahol közel 60-40\% volt a nők-férfiak aránya. A vizsgált minta 94\%-ban fedi le a célcsoport életkorát (18-35 év közötti fiatal felnőttek), így a fennmaradó 9 fő is bekerült a vizsgálatokba.

\begin{tabular}{|c|c|c|c|}
\hline Item & Kategória & $N$ & Arány (\%) \\
\hline \multirow[t]{3}{*}{ Nem } & Férfi & 61 & $40,40 \%$ \\
\hline & Nő & 90 & $59,60 \%$ \\
\hline & Összesen & 151 & $100 \%$ \\
\hline \multirow[t]{5}{*}{ Kor } & $18-24$ & 123 & $81,50 \%$ \\
\hline & $25-34$ & 19 & $12,60 \%$ \\
\hline & $35-44$ & 2 & $1,30 \%$ \\
\hline & $45-$ & 7 & $4,60 \%$ \\
\hline & Összesen & 151 & $100 \%$ \\
\hline \multirow[t]{6}{*}{ Képzettség } & Nyolc általános vagy kevesebb & 0 & $0,00 \%$ \\
\hline & Középiskola & 101 & $66,90 \%$ \\
\hline & Szakirányú továbbképzés (OKJ, FOSZ) & 12 & $7,90 \%$ \\
\hline & Egyetem vagy főiskola & 36 & $23,80 \%$ \\
\hline & Doktori képzés & 2 & $1,30 \%$ \\
\hline & Összesen & 151 & $100 \%$ \\
\hline \multirow[t]{5}{*}{ Lakóhely } & Főváros & 4 & $2,60 \%$ \\
\hline & Megyei jogú város & 52 & $34,40 \%$ \\
\hline & Város & 79 & $52,30 \%$ \\
\hline & Falu & 16 & $10,60 \%$ \\
\hline & Összesen & 151 & $100 \%$ \\
\hline
\end{tabular}

2. táblázat: (saját szerkesztés, 2020)

A kitöltők végzettségüket tekintve, döntően középfokú, 23,8\%-uk egyetemi vagy főiskolai végzettségű. Ez arra utal, hogy a kitöltők jelentős része egyetemi tanulmányait folytató, felsőfokú végzettséggel még nem rendelkező, alap-

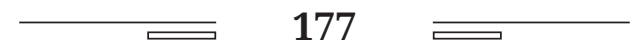


képzésben részt vevő hallgató, amely a hólabda módszerből adódhat. Emellett két fő rendelkezett doktori fokozattal. Lakóhely típusa szerint megállapítható, hogy a megyei jogú város lakói és a városban élők összesen a minta a 86\%-át teszik ki. A fővárosi és a falusi kitöltők aránya mindössze $4 \%$.

\section{Egészségügyi mobilapplikációk használata és feladások okai}

A kutatás kitért a megkérdezettek körében használt egészségügyi mobilapplikációk típusára és felhasználási területeire. Ennek eredményét a 3. ábra prezentálja, melyről jól látszik, hogy legtöbben lépésszámlálásra, a futás és biciklizés monitorozására, valamint diétájuk menedzselésére használnak alkalmazást. Érdekes tény, hogy a fiatal felnőttek körében is megjelennek az egészségügyi monitoringot használó applikációk, például a gyógyszerszedés, a vérnyomás vagy éppen a testsúly nyomon követésére.

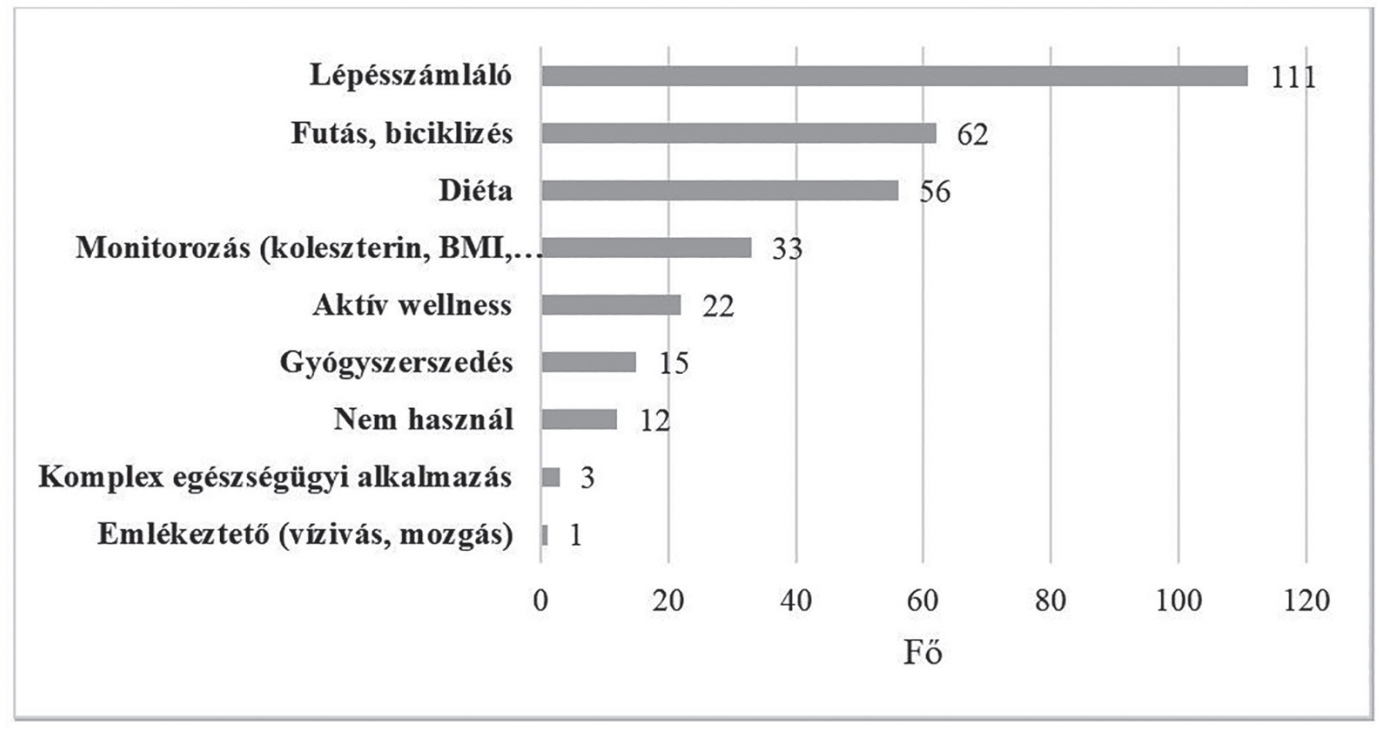

3. ábra: Használt applikáció típusok és megoszlásuk N=151 (saját szerkesztés, 2020)

A tanulmány részeként a szerzők ezen alkalmazások használati gyakorisága is mérésre került, illetve azok abbahagyásának legfőbb okait is mérték. Az alkalmazások használatának gyakoriságánál a 3. táblázat eredményei alapján megállapítható, hogy a fiatal felnőttek a lépésszámláló mellett a diétával, a monitorozással és a gyógyszerszedéssel kapcsolatos appokat használják naponta többször. Heti rendszerességgel használók esetén már kiegyenlített a verseny, ahol első helyre az aktív wellness (sport, jóga, fitnesz applikációk köre) került, második helyre pedig a futás és biciklizés teljesítmény figyelő applikációk kerültek. A havi rendszerességgel használók körében az aktív wellness és a futás, kerékpározás került az első két helyre. 


\begin{tabular}{|l|c|c|c|c|c|c|}
\hline \multicolumn{1}{|c|}{ Gyakoriság } & $\begin{array}{c}\text { Lépés- } \\
\text { számláló }\end{array}$ & $\begin{array}{c}\text { Futás, } \\
\text { biciklizés }\end{array}$ & Diéta & Monitorozás & $\begin{array}{c}\text { Aktív } \\
\text { wellness }\end{array}$ & $\begin{array}{c}\text { Gyógyszer- } \\
\text { szedés }\end{array}$ \\
\hline Naponta & $51 \%$ & $8 \%$ & $54 \%$ & $36 \%$ & - & $27 \%$ \\
\hline $\begin{array}{l}\text { Naponta több } \\
\text { alkalommal }\end{array}$ & $17 \%$ & $10 \%$ & $18 \%$ & $24 \%$ & - & $53 \%$ \\
\hline $\begin{array}{l}\text { Hetente } \\
\text { többször }\end{array}$ & $21 \%$ & $37 \%$ & $13 \%$ & $36 \%$ & $45 \%$ & $20 \%$ \\
\hline $\begin{array}{l}\text { Havonta több } \\
\text { alkalommal }\end{array}$ & $11 \%$ & $45 \%$ & $16 \%$ & $3 \%$ & $55 \%$ & - \\
\hline $\begin{array}{c}\text { Feladások } \\
\text { okai }\end{array}$ & $\begin{array}{c}\text { Lépés- } \\
\text { számláló }\end{array}$ & $\begin{array}{c}\text { Futás, } \\
\text { biciklizés }\end{array}$ & Diéta & Monitorozás & $\begin{array}{c}\text { Aktív } \\
\text { wellness }\end{array}$ & $\begin{array}{c}\text { Gyógyszer- } \\
\text { szedés }\end{array}$ \\
\hline $\begin{array}{l}\text { Túl bonyolult } \\
\text { volt }\end{array}$ & - & $2 \%$ & - & $3 \%$ & $2 \%$ & $1 \%$ \\
\hline Sok időt vett el & $2 \%$ & $2 \%$ & $5 \%$ & $3 \%$ & $1 \%$ & $1 \%$ \\
\hline $\begin{array}{l}\text { Elfeledkeztem } \\
\text { róla }\end{array}$ & $9 \%$ & $14 \%$ & $13 \%$ & $7 \%$ & $3 \%$ & $4 \%$ \\
\hline Meguntam & $6 \%$ & $5 \%$ & $9 \%$ & $7 \%$ & $5 \%$ & $4 \%$ \\
\hline $\begin{array}{l}\text { Elértem a } \\
\text { célom }\end{array}$ & - & $7 \%$ & $4 \%$ & $2 \%$ & $3 \%$ & $4 \%$ \\
\hline Egyéb & $6 \%$ & $5 \%$ & $3 \%$ & $3 \%$ & $4 \%$ & $4 \%$ \\
\hline
\end{tabular}

3. táblázat: Használt egészségügyi applikációk gyakorisága és abbahagyásuk okai (saját szerkesztés, 2020)

A kitöltők közel 87\%-a (132 fő) használt vagy jelenleg is használ valamilyen egészségügyi applikációt az okostelefonján, ezért a feladások okai erre a részsokaságra lett arányosítva. A táblázatról láthatjuk, hogy a legfőbb ok egy egészségügyi applikáció abbahagyására, hogy elfeledkeznek róla a felhasználók. Ezt követi a megunás és az, hogy sok időt vesz el a felhasználóktól az applikáció menedzselése.

\section{A modell elemzése}

Az egyes konstruktorok megbízhatóságának és érvényességének vizsgálatára konfirmatórikus faktoranalízis lett alkalmazva. Az egyes látens változók (konstrukciók) megbízhatóságát a Cronbach-féle a-mutató segítségével mértük. Alapvetően az a értékének meg kell haladnia a 0,7-es értéket, azonban feltáró jellegű elemzésnél ez az érték már 0,6-tól jónak számít (J. Hair és mtsai. 2014). A 4. táblázat alapján megállapítható, hogy a kritérium egy esetet leszámítva (FC $\alpha=0,508$ ) mindenhol teljesül, azonban meghaladja a 0,5-ös küszöbértéket, így elfogadhatónak mondható. 
A konvergenciaérvényesség ellenőrzésére a standardizált faktorsúlyoknak és az átlagos kivonatolt varianciának (Average Variance Extracted (AVE) meg kell haladnia a 0,5-ös küszöbértéket, továbbá az összetétel-megbízhatósági mutatónak (composition reliability (CR) a 0,7-es értéknél kell magasabbnak lennie (J. Hair és mtsai. 2014). A küszöbértékekhez hasonlítva a 4. táblázat eredményeit, elmondható, hogy az öt konstruktor létezéséből négy igazolható.

\begin{tabular}{|c|c|c|c|c|}
\hline Konstrukciók & Item & $\begin{array}{c}\text { Standardizált } \\
\text { faktor súly }\end{array}$ & Átlag & Szórás \\
\hline \multirow{4}{*}{$\begin{array}{l}\text { Várható teljesít- } \\
\text { mény (PE) } \\
\alpha=0,825 \\
A V E=0,660 \\
C R=0,876\end{array}$} & $\begin{array}{l}\text { Hasznosnak találnám az egészségügyi } \\
\text { applikációkat. }\end{array}$ & 0,761 & 3,99 & 0,88 \\
\hline & $\begin{array}{l}\text { Az applikáció(k) használata lehetővé } \\
\text { teszi számomra az egészségem } \\
\text { megőrzésével kapcsolatos teendők } \\
\text { elvégzését. }\end{array}$ & 0,893 & 3,58 & 1,05 \\
\hline & $\begin{array}{l}\text { Az egészségügyi applikáció(k) } \\
\text { használata elősegíti(k) a jó } \\
\text { közérzetem fenntartását. }\end{array}$ & 0,861 & 3,17 & 1,17 \\
\hline & $\begin{array}{l}\text { Ha használnék egészségügyi } \\
\text { applikációkat, egészségesebb } \\
\text { lehetnék. }\end{array}$ & 0,723 & 3,05 & 1,19 \\
\hline \multirow{4}{*}{$\begin{array}{l}\text { Várható elvárt } \\
\text { erőfeszítés (EE) } \\
\begin{array}{l}\alpha=0,838 \\
\mathrm{AVE}=0,682 \\
\mathrm{CR}=0,894\end{array}\end{array}$} & $\begin{array}{l}\text { Könnyü megtanulni az egészségügyi } \\
\text { applikációk használatát. }\end{array}$ & 0,835 & 4,15 & 0,94 \\
\hline & $\begin{array}{l}\text { Átlátom az egészségügyi applikációk } \\
\text { működését. }\end{array}$ & 0,933 & 3,92 & 1,05 \\
\hline & $\begin{array}{l}\text { Az egészségügyi applikációk } \\
\text { használatát könnyünek tartom. }\end{array}$ & 0,872 & 3,99 & 0,96 \\
\hline & $\begin{array}{l}\text { Más mobilalkalmazásokhoz képest } \\
\text { nem nehezebb az egészségügyi } \\
\text { applikációkat használnom. }\end{array}$ & 0,633 & 3,93 & 1,17 \\
\hline \multirow{3}{*}{ 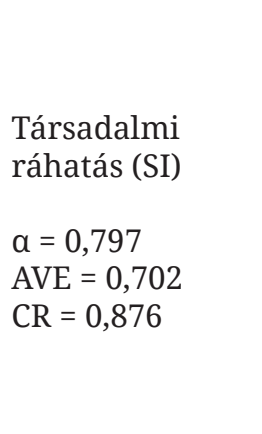 } & $\begin{array}{l}\text { Családtagjaim szerint használnom } \\
\text { kellene valamely egészségügyi } \\
\text { mobilapplikációt. }\end{array}$ & 0,838 & 1,75 & 1,14 \\
\hline & $\begin{array}{l}\text { A barátaim azt gondolják, hogy } \\
\text { használnom kellene egészségügyi } \\
\text { applikációt. }\end{array}$ & 0,856 & 1,73 & 1,12 \\
\hline & $\begin{array}{l}\text { A közösségi médiában ismerőseim } \\
\text { által megosztott egészségügyi } \\
\text { mobilapplikációkat én is szivesen } \\
\text { kipróbálom. }\end{array}$ & 0,818 & 2,63 & 1,33 \\
\hline
\end{tabular}




\begin{tabular}{|c|c|c|c|c|}
\hline Konstrukciók & Item & $\begin{array}{l}\text { Standardizált } \\
\text { faktor súly }\end{array}$ & Átlag & Szórás \\
\hline \multirow{4}{*}{$\begin{array}{l}\text { Könnyítő feltéte- } \\
\text { lek (FC) } \\
a=0,508 \\
\text { AVE }=0,397 \\
C R=0,718\end{array}$} & $\begin{array}{l}\text { Az okostelefonom nélkül nem tudok } \\
\text { létezni. }\end{array}$ & 0,428 & 2,82 & 1,32 \\
\hline & $\begin{array}{l}\text { Megfelelő tudással rendelkezem } \\
\text { az okostelefonos applikációk } \\
\text { használatában. }\end{array}$ & 0,660 & 4,07 & 0,99 \\
\hline & $\begin{array}{l}\text { Az egészségügyi alkalmazások, } \\
\text { melyeket használok, kapcsolatban } \\
\text { vannak más technológiákkal, amiket } \\
\text { használok (Bluetooth, Wifi). }\end{array}$ & 0,762 & 3,65 & 1,23 \\
\hline & $\begin{array}{l}\text { Számíthatok mások segítségére, } \\
\text { ha elakadok egy mobilapplikáció } \\
\text { használata közben. }\end{array}$ & 0,624 & 3,70 & 1,25 \\
\hline \multirow{3}{*}{$\begin{array}{l}\text { Hedonista moti- } \\
\text { váció (HM) } \\
a=0,808 \\
A V E=0,702 \\
C R=0,876\end{array}$} & $\begin{array}{l}\text { Az egészségügyi alkalmazásokat } \\
\text { szórakoztatónak tartom. }\end{array}$ & 0,763 & 2,87 & 1,11 \\
\hline & $\begin{array}{l}\text { Örömmel használok egészségügyi } \\
\text { applikációkat. }\end{array}$ & 0,889 & 3,28 & 1,09 \\
\hline & $\begin{array}{l}\text { Nagyban hozzájárul a motivációmhoz } \\
\text { az egészségügyi applikációk } \\
\text { használata. }\end{array}$ & 0,885 & 3,11 & 1,26 \\
\hline
\end{tabular}

4. táblázat: A konstrukciók és a hozzájuk kapcsolódó indikátorok ${ }^{2}$ (saját szerkesztés, 2020)

\begin{tabular}{|c|c|c|c|c|c|c|c|c|}
\hline Konstruktorok & $\boldsymbol{C R}$ & $\mathbf{A V E}$ & $\mathbf{B I}$ & $\mathbf{E E}$ & $\mathbf{F C}$ & HM & PE & SI \\
\hline BI & $\mathbf{0 , 8 8 1}$ & $\mathbf{0 , 7 1 2}$ & 1 & 0,228 & 0,132 & 0,496 & 0,421 & 0,395 \\
\hline EE & $\mathbf{0 , 8 9 4}$ & $\mathbf{0 , 6 8 2}$ & 0,228 & 1 & 0,188 & 0,22 & 0,23 & 0,01 \\
\hline FC & $\mathbf{0 , 7 1 8}$ & 0,397 & 0,132 & 0,188 & 1 & 0,169 & 0,155 & 0,125 \\
\hline HM & $\mathbf{0 , 8 8 4}$ & $\mathbf{0 , 7 1 9}$ & 0,496 & 0,22 & 0,169 & 1 & 0,42 & 0,334 \\
\hline PE & $\mathbf{0 , 8 8 5}$ & $\mathbf{0 , 6 6}$ & 0,421 & 0,23 & 0,155 & 0,42 & 1 & 0,302 \\
\hline SI & $\mathbf{0 , 8 7 6}$ & $\mathbf{0 , 7 0 2}$ & 0,395 & 0,01 & 0,125 & 0,334 & 0,302 & 1 \\
\hline
\end{tabular}

5. táblázat: (saját szerkesztés, 2020)

A diszkriminancia érvényesség ellenőrzése több mérés található a szakirodalomban, amelyek közül ez a Fornel-Larcker tesztje alapján történt (Fornell és Larcker 1981). Kimondja, hogy az adott látens változó AVE-értékének maga-

\footnotetext{
$\overline{2}$ Megjegyzés. Az itemek mérése Likert-skálákon (1-5) történt. Az a a Cronbach-féle mutatót, az AVE az átlagos kivonatolt varianciát, a CR pedig az összetétel-megbízhatósági mutatót jelöli. Az egyes itemek Venkatesh munkája alapján kerültek beválogatásra (Venkatesh, Thong és Xu 2012).
} 
sabbnak kell lennie, mint a többi látens változó közötti korreláció négyzete. $\mathrm{E}$ számítások eredményeit a 5. táblázat értékei prezentálják. Ezek alapján a kritérium teljesül a könnyítő feltételeket (FC) leszámítva, amely azt jelenti, hogy az egyes faktorok az FC kivételével elkülönülnek egymástól.

Ezt követően az utak tesztelésének eredményeit az 6. táblázat szemlélteti. Az útegyütthatók tesztelésére bootstrap mintavételi eljárás lett végrehajtva, ahol 10\%-os szignifikanciai küszöbérték lett megadva, valamint az eljárás 1000-es iterációval futott le. A táblázat p-értékei alapján megállapítható, hogy a könnyítő feltételek (FC) kivételével a további négy független változó (EE, HM, PE, SI) szignifikáns hatást fejt ki a függő változóra (BI).

\begin{tabular}{|l|c|c|c|c|c|}
\hline \multicolumn{1}{|c|}{ Út } & $\begin{array}{c}\text { Útegyüttható } \\
\text { (eredeti } \\
\text { minta) }\end{array}$ & $\begin{array}{c}\text { Útegyüttható } \\
\text { átlaga } \\
\text { (bootstrap } \\
\text { mintákból) }\end{array}$ & $\begin{array}{c}\text { Utegyüttható } \\
\text { szórása } \\
\text { (bootstrap } \\
\text { mintákból) }\end{array}$ & t-érték & p-érték \\
\hline EE -> BI & 0,137 & 0,130 & 0,062 & 2,185 & $<0,029$ \\
\hline FC -> BI & $-0,069$ & $-0,045$ & 0,057 & 1,176 & $<0,240$ \\
\hline HM -> BI & 0,443 & 0,440 & 0,075 & 5,864 & $<0,000$ \\
\hline PE -> BI & 0,173 & 0,176 & 0,068 & 2,561 & $<0,011$ \\
\hline SI -> BI & 0,290 & 0,288 & 0,064 & 4,539 & $<0,000$ \\
\hline
\end{tabular}

6. táblázat: A bootstrap eljárás eredménye (saját szerkesztés, 2020)

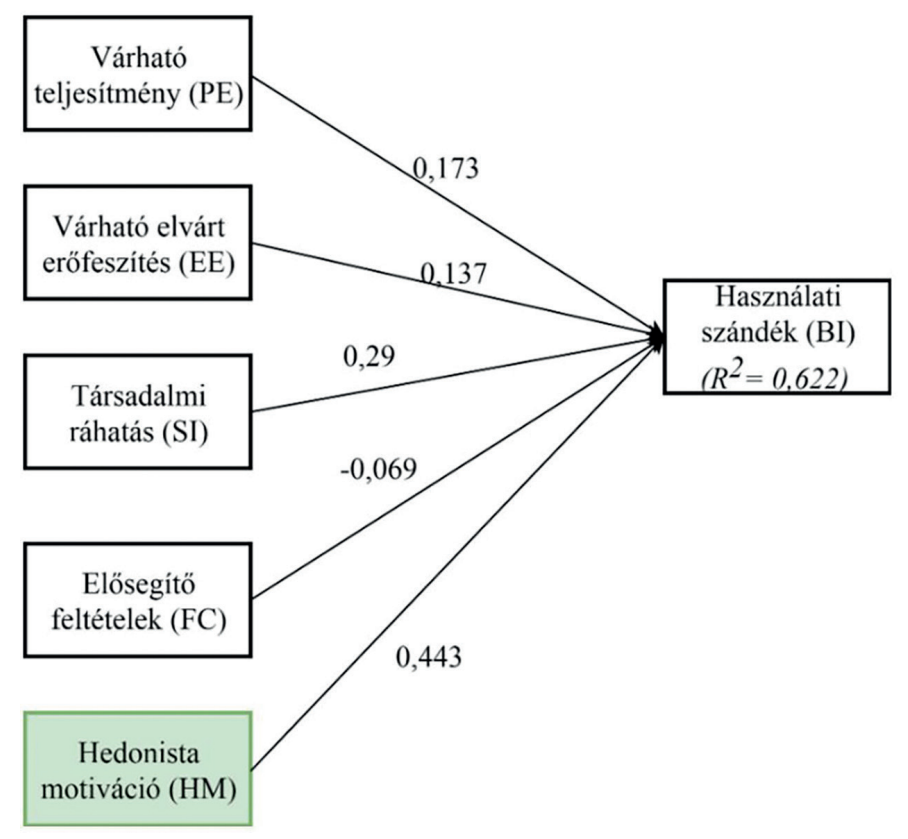

4. ábra: Az egyes faktorok szerepe az egészségügyi mobilapplikációk használati szándákára a modellben (módosított UTAUT) (saját szerkesztés, 2020) 
E szignifikáns hatások mentén a kialakított modellt a 4. ábra mutatja be számunkra. A modell exogén változói így a várható teljesítmény (PE), a várható elvárt erőfeszítés (EE), a társadalmi ráhatás (SI), valamint a hedonista motiváció és a használati szándék (BI) lett. Az egyes közvetlen hatások a modellben a nyilakon feltűntetett standardizált útegyütthatókkal történt, ahol megállapítható, hogy minden szignifikáns kapcsolat esetén pozitív hatás tapasztalható. Megállapítható, hogy a legerőteljesebben (egészségügyi applikációk használati szándékában) a hedonista motivációnak van szerepe $(\beta=0,443)$. Ezt követi a társadalmi ráhatás (SI) $(\beta=0,290)$, míg a várható elvárt erőfeszítés $(\beta=0,137)$ (EE) és a várható teljesítmény (PE) $(\beta=0,173)$, együttes hatása ér csak fel a rangsorban a második érték (SI) hatásához. Összességében tehát a használati szándék (BI) magyarázóereje 62,2\%, amelyre a leginkább a hedonista motiváció (HM) és a társadalmi ráhatás (SI) hat.

\section{Konklúzió}

Jelen kutatásban a szerzők megvizsgálták az egészségügyi mobilapplikációk használati szándékát és azok befolyásoló tényezőit egy módosított UTAUT-modell segítségével. A kérdőíves felmérésben 151 fiatal felnőtt (18 és 35 év közötti) vett részt önkéntesen. A vizsgálat exploratív jellegű volt, így előzetes hipotézisek nem lettek felállítva. Limitáló tényezőként a moderáló változók elhagyása jelent meg a tanulmányban, melyet egy későbbi kutatás alapját adhatja. Érdemes lehet megvizsgálni, milyen hatást fejt ki a kor vagy a nem az egyes faktorokra. Az eredmények tükrében elmondható, hogy az egészségügyi mobilappok használati szándékát leginkább a hedonista motiváció befolyásolja. A szerzők arra következtetnek, hogy mivel az egészség és fittség leginkább belső motivációból ered, így ezért ez a faktor a leginkább befolyásoló tényező a fiatalok körében. Ezenfelül, a konstruktorok bemutatásánál is felmerült, hogy ez az a változó, ami a technológia használatából eredő élmény és szórakozást jelenti a felhasználóra. Az egyes cselekvést nem kényszerként éli meg, így annak élvezeti értékét a felhasználók jóval magasabbra értékelik.

A modell eredményeit tekintve az is kiderült, hogy a szociális ráhatásnak szintén nagy szerepe van a használati hajlandóságra, amely mögött a közösség és ismerősök által való megítélés vagy segítő szándék állhat. Emellett a szerzők úgy vélik, a közösségi médián történő teljesítmény megosztásának egyfajta presztízsértéket társíthatnak, amely az SI változó szerepét magyarázhatja. Felmerülhet a kérdés, hogy a felhasználók önszántukból telepítik-e ezeket az alkalmazásokat, vagy az egyes média és társadalmi hatások miatt cselekszenek egyik oldalról, míg másik oldalról orvosaik javaslatára, utasítására. A modellben a segítő feltételek (FC) mint faktor, szignifikánsan nem kimutatható, amely adódhat a változó alacsony megbízhatóságából. Hatását és értelmezését tekintve azonban a szerzők azzal magyarázzák, hogy a fiatal korosztály 
napi szinten használ okostelefont és mobilapplikációkat életvitelük során, így az eszközhasználat és a háttértudás a kitöltők számára releváns.

A tanulmány emellett felmérte a kitöltők által használt egészségügyi applikációk típusait és azok gyakoriságát. Megállapítható, hogy gyakoriság szempontjából első helyen áll a legkisebb erőfeszítést igénylő lépésszámláló, melyet rendre a diéta, a monitorozás és a gyógyszerszedést támogató applikációk követtek. A lépésszámláló esetén hasonló eredményre jutott Ráthonyi és kollégái (Ráthonyi és mtsai. 2019). A heti és havi használat esetén azonban az aktív wellness és a futás-biciklizés teljesítménymérésére szolgáló applikációk kerültek előtérbe. Az egyes applikációcsoportok feladásának okai közül első helyen áll, hogy napi teendőik mellett a felhasználók elfelejtenek az okostelefonjuk után nyúlni. Második helyen a megunás áll, ahol a válaszadók fejlesztési tanácsokat is adhattak meg a kérdések mellé. Többen a monotonitás feloldását és több játékosságot, pontot, jutalmat vártak el egy-egy alkalmazástól és a fejlesztőiktől. Emellett kisebb arányban megjelenik, hogy sok időt vesz el a használatuk, illetve többen elérték a céljukat, ami miatt telepítették az adott alkalmazást. Zhang és kollégája hasonló problémákat tapasztal mobilapplikációk területén, melyre egy fejlesztői sémát is javasoltak (Zhang és Polytechnic 2014). Végül az egyéb tényező és a bonyolultság volt a legkevésbé hátráltató tényező a feladás okai között. Ennek oka pedig vélhetően a célcsoport korosztálya, akik készségszinten használják okostelefonjukat.

Az eredményeket és a szakirodalmat tekintve a szerzők a következtetéseken túl az egészségügyi mobilapplikációk használatának felértékelődését, valamint nagyobb mértékű alkalmazását várják a közeljövőben. Ennek egyik oka a pandémia, amely a személyes találkozásokon túl a különböző mozgásformákat, aktív kikapcsolódást, valamint a sportolási lehetőségeket erőteljesen szűkíti. A szerzők a diétát segítő, valamint az egyes monitorozó, edzést segítő alkalmazások letöltéseiben kiugró eredményeket várnak az előző évekhez képest. Emellett véleményük szerint a szakirodalmi részben is bemutatott hitelesség, adataink védelme az elérhetőség mellett egyre fontosabb szerepet tölt be a felhasználók használati szándéka és a tényleges használat kapcsolatában.

\section{Irodalom}

Ajzen, Icek. és Fishbein Martin. „Understanding attitudes and predicting social behavior” Prentice-Hall, Englewood Cliffs NJ (1980)

Alsyouf, Adi, és Awanis Ku Ishak. „Understanding EHRs continuance intention to use from the perspectives of UTAUT: Practice environment moderating effect and top management support as predictor variables”. International Journal of Electronic Healthcare 10 (1-2) (2018): 24-59. https://doi.org/10.1504/IJEH.2018.092175. 
Amaro, J. Pedro., és Patrão, Sérgio. „A survey of sensor fusion algorithms for sport and health monitoring applications." In IECON 2016-42nd Annual Conference of the IEEE Industrial Electronics Society (2016, October): pp. 5171-5176.

Aroganam, Gobinath, Manivannan, Nadarajah., és Harrison, David.”Review on wearable technology sensors used in consumer sport applications.” Sensors, 19(9), (1983)

Boudreaux, Edwin D., Molly E. Waring, Rashelle B. Hayes, Rajani S. Sadasivam, Sean Mullen, és Sherry Pagoto. „Evaluating and selecting mobile health apps: strategies for healthcare providers and healthcare organizations”. Translational Behavioral Medicine 4 (4) (2014): 363-71. https://doi.org/10.1007/s13142-014-0293-9.

Briz-Ponce, Laura, és Francisco José García-Peñalvo. „An Empirical Assessment of a Technology Acceptance Model for Apps in Medical Education”. Journal of Medical Systems 39 (11). (2015) https://doi.org/10.1007/s10916-015-0352-x.

Chang, Andreas. „UTAUT and UTAUT 2: A review and agenda for future research.” The Winners, 13 (2), (2012): 10-114.

Dajani, Dima. "Using the unified theory of acceptance and use of technology to explain e-commerce acceptance by Jordanian travel agencies” J. Comp. Int. Manag., 19 (1) . (2016): 121-144

Davis, Fred D. „Perceived usefulness, perceived ease of use, and user acceptance of information technology”. MIS Quarterly: Management Information Systems 13 (3) (1989): 319-39. https:/l doi.org/10.2307/249008.

Duyck, Philippe, B. Pynoo, P. Devolder, T. Voet, L. Adang, és J. Vercruysse. „User acceptance of a picture archiving and communication system: Applying the unified theory of acceptance and use of technology in a radiological setting”. Methods of Information in Medicine 47 (2) (2008): 149-56. https://doi.org/10.3414/ME0477.

Erdei Gergő, Kovács Viktória Anna, Bakacs Márta és Martos Éva. „Országos Táplálkozás és Tápláltsági Állapot Vizsgálat 2014: A magyar felnőtt lakosság tápláltsági állapota”. Orvosi Hetilap 158 (14) (2017): 533-40. https://doi.org/10.1556/650.2017.30700.

Europian Comission. „Sport and physical activity.” Special Eurobarometer 472 (2018)

Fornell, Claes, és David F. Larcker. „Evaluation Structural Equation Models with Unobservable Variables and Measurement Error”. Journal of Marketing Research 18 (1) (1981): 39-50.

Greve, Maike, Lembcke, Tim-Benjamin, Diederich, Stephan, Brendel, Alfred. B., és Kolbe, Lutz. M. „Healthy by App-Towards a Taxonomy of Mobile Health Applications.”PACIS 2020. (2020) Hair, Joe F., Christian M. Ringle, és Marko Sarstedt. „PLS-SEM: Indeed a silver bullet”. Journal of Marketing Theory and Practice 19 (2) (2011): 139-51. https://doi.org/10.2753/MTP10696679190202.

Hair, Joseph, William Black, Barry Babin, és Rolph Anderson. „Multivariate Data Analysis. Exploratory Data” Analysis in Business and Economics. (2014) https://doi.org/10.1007/9783-319-01517-0 3.

Han, Myeunghee, és Eunjoo Lee. „Effectiveness of Mobile Health Application Use to Improve Health Behavior Changes : A Systematic Review of Randomized Controlled Trials” 24 (3) (2018): 207-26.

Henseler, Jörg, Christian M. Ringle, és Rudolf R. Sinkovics. „The use of partial least squares path modeling in international marketing”. Advances in International Marketing 20 (2009): 277-319. https://doi.org/10.1108/S1474-7979(2009)0000020014. 
Hootsuite, és We are Social „Digital in Hungary 2018”. 2018. Utolsó hozzáférés: 2020. december 14. https://datareportal.com/digital-in-hungary.

Höhn Matthias, von Jan Ute, Framke Theodor és Albrecht Ursvito. „Classification of Health Related Applications.” Studies in Health Technology and Informatics. 226 (2016): 139-142.

Hung, Ming Chien, és Wen Yuan Jen „The adoption of mobile health management services: An empirical study”. Journal of Medical Systems 36 (3) (2012): 1381-1388. https://doi. org/10.1007/s10916-010-9600-2.

Kang, Ju-young M, Jung Mee, és Kim K P Johnson. „Computers in Human Behavior In-store mobile usage : Downloading and usage intention toward mobile location-based retail apps”. Computers in Human Behavior 46 (2015): 210-217. https://doi.org/10.1016/j.chb.2015.01.012. Kazár Klára. „A PLS-útelemzés és alkalmazása egy márkakö- zösség pszichológiai érzetének vizsgálatára”. Statisztikai Szemle 92 (1) (2014): 33-52.

Keszei Tamara és Zsukk János. „Az új technológiák fogyasztói elfogadása”. Vezetéstudomány 48 (10) (2017): 38-47.

Kovács Viktória Anna. „A gyermekkori elhízás népegészségügyi vonatkozásai”. Egészségfejlesztés LIX (2018. 4.): 34-37. https://doi.org/10.24365/ef.v59i4.348.

Kő Andrea és Szabó Zoltán. „Innovatív e-egészségügyi megoldások - A jövő internetes technológiái a távmonitorozásban”. Pro Publico Bono: Magyar Közigazgatás 4 (2015): 6-21. Központi Statisztikai Hivatal (KSH). „ Magyarország, 2018.” (2019) ISSN: 1416-2768

Lee, Hannah, Kyeong Eun Uhm, In Yae Cheong, Ji Sung Yoo, Seung Hyun Chung, és Yong Hyun Park. „Patient Satisfaction with Mobile Health ( mHealth ) Application for Exercise Intervention in Breast Cancer Survivors”. (2018)

Lupton, Deborah „Apps as Artefacts: Towards a Critical Perspective on Mobile Health and Medical Apps”. Societies 4 (4) (2014): 606-22. https://doi.org/10.3390/soc4040606.

Maldonado, U. P. Torres, Khan, G. Feroz, Moon, Junghoon, Rho, J. Jae. „E-learning motivation and educational portal acceptance in developing countries.” Online Information Review, 35 (1),(2011): 66-85. doi: 10.1108/14684521111113597

Mohamed, Abdul Hakim H.M., Hissam Tawfik, Dhiya Al-Jumeily, és Lin Norton „MoHTAM: A technology acceptance model for mobile health applications”. Proceedings - 4th International Conference on Developments in eSystems Engineering, (2011, sz. December): 13-18. https://doi.org/10.1109/DeSE.2011.79.

Ndayizigamiye, Patrick, és Manoj Maharaj. „Mobile health adoption in Burundi: A UTAUT perspective”. GHTC 2016 - IEEE Global Humanitarian Technology Conference: Technology for the Benefit of Humanity, Conference Proceedings, (2016):613-23. https://doi.org/10.1109/ GHTC.2016.7857342.

Nemzeti Média- és Hírközlési Hatóság „Lakossági internethasználat”(2018)

Nielsen, Brandorff. „Mobil applikációk amit nem árt, ha tudsz, mielőtt belevágnál a fejlesztésbe!” (2014)

Nwe, Knive, Larsen Mark Erik, Nelissen Natalie, és Wong, David. Chi-Wai. „Medical Mobile App Classification Using the National Institute for Health and Care Excellence Evidence Standards Framework for Digital Health Technologies: Interrater Reliability Study.” Journal of medical Internet research, 22(6) (2020): 174-79.

OECD Health statistic. „Obesity Update 2017”. Diabetologe 13 (5) (2017) 331-41. https://doi. org/10.1007/s11428-017-0241-7. 
Ráthonyi Gergely, Ráthonyi-Odor Kinga, Elena, Bendínková, és Bácsné Bába Éva. „Wearable Activity Trackers Usage among University Students”. European Journal of Contemporary Education 8 (3) (2019): 600-612. https://doi.org/10.13187/ejced.2019.3.600.

Sajtos Lálszló és Fache, Michelle. 2005. „A strukturális egyenlőségek módszere és alkalmazása a marketingkutatásban”. Marketing \& Menedzsment 39 (4-5): 99-111.

Seabrook, J. Heather, Stormer N Julie, Shevkenek Cole, Bharwani Aleem, Grood de Jil és Ghali A William. „Medical applications: a database and characterization of apps in Apple iOS and Android platforms.” BMC research notes, 7(1) (2014): 1-8.

Shin, Dong-Hee. „Towards an understanding of the consumer acceptance of mobile wallet Original Research Article.” Computers in Human Behavior, 25, (2009) 1343-1354. doi: 10.1016/j.chb.2009.06.001

Soós János és Törőcsik Mária. „Okoseszközökre telepíthető egészségügyi alkalmazások trendspotting kutatás eredményei.” Kiadó: Pécsi Tudományegyetem, (2015) ISBN 978-963642-988-1,

Szivós Péter és Tóth István. „Egyenlőtlenség és polarizálódás a magyar társadalomban”. 2013 Van der Heijden, Hans. „User acceptance of hedonic information systems.” MIS quarterly, (2004): 695-704.

Venkatesh, Viswanath, és Fred D. Davis. „Theoretical extension of the Technology Acceptance Model: Four longitudinal field studies”. Management Science 46 (2) (2000): 186-204. https:/l doi.org/10.1287/mnsc.46.2.186.11926.

Venkatesh, Viswanath, és Hillol Bala. „Technology acceptance model 3 and a research agenda on interventions”. Decision Sciences 39 (2) (2008): 273-315. https://doi.org/10.1111/j.15405915.2008.00192.x.

Venkatesh, Viswanath, James Y.L. Thong Thong, és Xin Xu. „Consumer Acceptance and Use of IT”. Forthcoming in MIS Quarterly 36 (1) (2012): 157-78.

Venkatesh, Viswanath, Michael G Morris, Monroe Hall, Gordon B Davis, és Fred D Davis. „arterly” 27 (3) (2003): 425-78.

Wills, Matthew J. „Examining Healthcare Professionals’ Acceptance of Electronic Medical Records Using Utaut”. Issues in Information Systems 9 (2) (2008): 396-401.

World Health Organization. „Hungary.” (2013)

Yasini Mobin és Marchand Guillaume. „Toward a use case based classification of mobile health applications.” Studies in Health Technology and Informatics. 210 (2015):175-179.

Zhang, Chi, és Southern Polytechnic. „Assessment metrics, challenges and strategies for mobile” 15 (Ii)(2014): 59-66. 